\title{
Palaeofaunal sites and excavations
}

\author{
Trevor H. Worthy \\ School of Biological, Earth and Environmental Sciences, The University of New South Wales
}

Atholl Anderson

Department of Archaeology and Natural History, The Australian National University

\section{Introduction}

Fieldwork investigating fossil sites occurred in Fiji between June 1997 and November 1999. We concentrated on the limestone areas of Viti Levu, but also investigated the upraised coral island of Vatulele. Access and permission to the various sites was facilitated by the Fiji Museum, in particular by Sepeti Matararaba (Fiji Museum Field Officer). All research on fossil sites was directed by Worthy, as follows:

1. In June 1997, assisted by Matararaba and Gavin Udy (New Zealand caver), we made a preliminary survey of caves in the Sigatoka Valley. Limestone areas around Volivoli, Raiwaqa, Toga, Tuvu and Saweni were examined (Figure 9). Most caves had no or few fossils. In a few sites, small collections of recent bones were made from cave entrances, where Tyto alba (lulu, or barn owl) had been nesting.

2. In March-April 1998, assisted by Anderson, Matararaba and Tarisi Sorovi-Vunidilo (Fiji Museum), work continued in the Volivoli and Tuvu areas. The previously unrecorded caves at Tau (Nakidro Land Division) were also examined and the former falcon colony at Joskes Thumb was visited.

3. In October 1998, assisted by Matararaba and Udy, a brief visit to the Volivoli caves was made with Fiji Museum staff and students from the University of the South Pacific. Most of the time, however, was spent examining caves in the Wainibuku area near Suva. These were Wainibuku Cave, Udit Cave and Dharam Singh Cave, sensu Gilbert (1984). A visit to Wailotua was also made and two caves were prospected for fossils - the main Wailotua Cave and Delaniqara.

4. In November 1999, assisted by Matararaba, Jone Naucabalavu (Fiji Museum) and Udy, limestone outcrops in the hills about $14 \mathrm{~km}$ inland of Nadi near Nawaqadamu village were investigated. Caves were again visited in the Wainibuku Valley, and a visit was made 


\section{VITI LEVU}

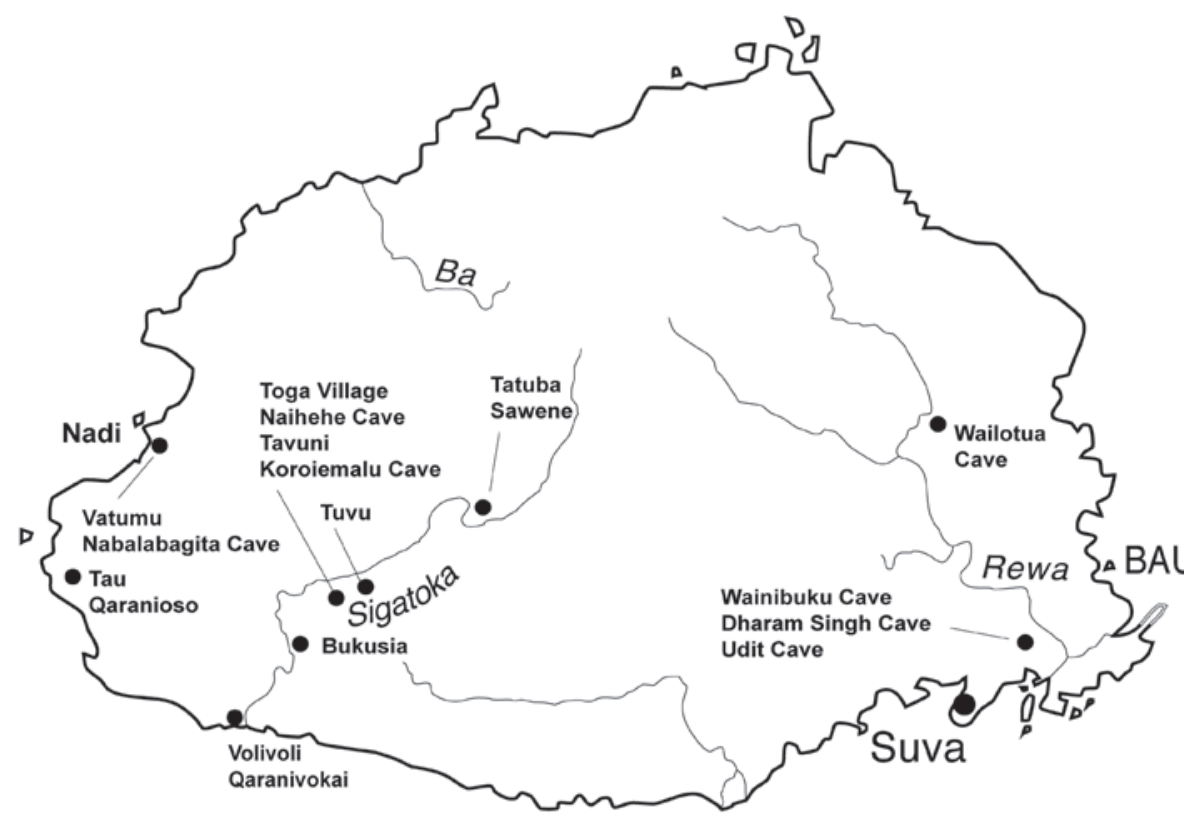

YANUCA $^{\circ}$ SBBEA

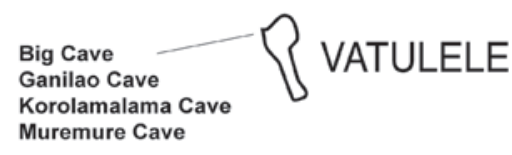

Figure 9. Viti Levu, showing locations where fossil sites were searched for.

to Naivucini, near Vunidawa, to look at cliffs that peregrine falcons were reported still to inhabit. Ledges high on the cliff may warrant investigation for fossil deposits, but were inaccessible with the equipment at hand. The team also revisited Delaniqara at Wailotua for a more detailed examination of the cave. A cave nearby, with a $20 \mathrm{~m}$ entrance pitch into a regularly flooded chamber with a large stream and a large bat colony in the roof, was explored but no fossil deposits were found. The work on Vatulele Island also occurred during this period of fieldwork.

In the descriptions which follow, grid references to sites are on the 1:50,000 Series 31 topographical maps. Latitude and longitude were obtained using a Garmin 38 GPS instrument. Fossils were either collected from cave floors or excavated from sediment by trowel. Unconsolidated sediments were sieved with $6 \mathrm{~mm}, 4 \mathrm{~mm}$ or $2 \mathrm{~mm}$ sieves, using the smallest mesh that was possible in each circumstance, and the sediment retained on the finer mesh was sorted under laboratory conditions. Subsequent bone conservation treatment, restoration and identification was accomplished by Worthy. All fossils are catalogued in the fossil bird collection of the Museum of New Zealand Te Papa Tongarewa, Wellington, New Zealand, and the results are listed in the following chapter. 


\section{Fossil sites in the Sigatoka Valley: Volivoli Cave system}

Location: L29 659713; edition 1, 1992; 180 09' 39"S, 1770 28' 53"E. Visits: Investigations were conducted in this cave (Figure 10) on several occasions: 4, 14 and 16 June 1997; 25-28 March, 1 April and 30 September 1998.

\section{Volivoli submergence}

Archaeological structures (walls) and midden deposits are in primary position in the main submergence entrance, but the latter have been eroded by intermittent stream flows and spread along the stream bed of the cave for about $150 \mathrm{~m}$. Examination of the debris in the stream bed revealed many undecorated pottery sherds and shells, but no bones of food species. Several fragments of adzes were collected from the stream bed by Matararaba and placed in the Fiji Museum. Remains of three human burials were noted in the cave: one at the entrance, one in an alcove opposite and immediately downstream of the fossil site, and one at the end of the side passage downstream of and on the same side as the fossil site. The cave is generally about $8 \mathrm{~m}$ wide for the first $60 \mathrm{~m}$ and the stream has eroded sediments down to clean rock along its bed throughout this area. Beside the stream, banks of red, lateritic, silty clay remain in places. The floors of all sediment surfaces and the sections in the sediment banks were examined for fossils. About $50 \mathrm{~m}$ from the entrance, the Volivoli fossil site 1 (VV1) was discovered on the true left (Figure 10).

\section{Volivoli fossil site 1}

Volivoli 1 is the first fossil site containing Quaternary terrestrial animal remains to be located in Viti Levu. It is a steep, $5 \mathrm{~m}$ high bank of mainly clay sediment with some boulders that appear to be coming into the cave from a now-blocked entrance. A few metres further into the cave, a hole in the roof leads into a steeply ascending passage, which appears to come from the same old entrance. It was too difficult to follow this passage up slope, but midden debris (Trochus shells and some bivalves) were on the floor of this passage, presumably having been washed into the cave during wet periods. Overlying this site on the surface is a doline, which has a rock shelter (Volivoli III) in it from which a shaft drops into the roof at VV1. The deposit in which the fossils occur is a consolidated, red lateritic silty-clay matrix, which forms part of a once more extensive cave infill. The bones are very sparse and also generally very fragmented, making their recovery difficult. The consolidated silty-clay nature of the sediment precluded wet-sieving methods to extract fossils, nor was this desirable as it would have destroyed the association of the bone fragments. The fossils were kept associated in sediment, and dried, after which the clay was able to be rinsed off under a gentle flow of water. The bones were then redried and reconstructed.

The taphonomy of VV1 is difficult to interpret but the fragmented nature of the material, which comprises mainly terrestrial species, suggests it may have been scavenged or predated, probably by the crocodilian (below). Fossils were buried in massive unstructured sediment with limestone rocks, so fluvial deposition can be ruled out. Subsequent diagenesis has resulted in sediment compaction and crushing of many fossils. The presence of slickensides in the clay sediments indicates that it has been alternatively wet and dried to some extent and the associated expansion and contraction probably contributed to the bone fragmentation.

The undisturbed sediment contained no charcoal inclusions (although fine charcoal fragments derived from coconut torches are common on surfaces), was unstratified, and was not capped by any speleothem deposits, thus dating by methods employing these elements was not possible. Samples of crocodile and other bone were submitted to Beta Analytic for AMS radiocarbon dating. However, they were found to contain no collagen, so direct radiocarbon 


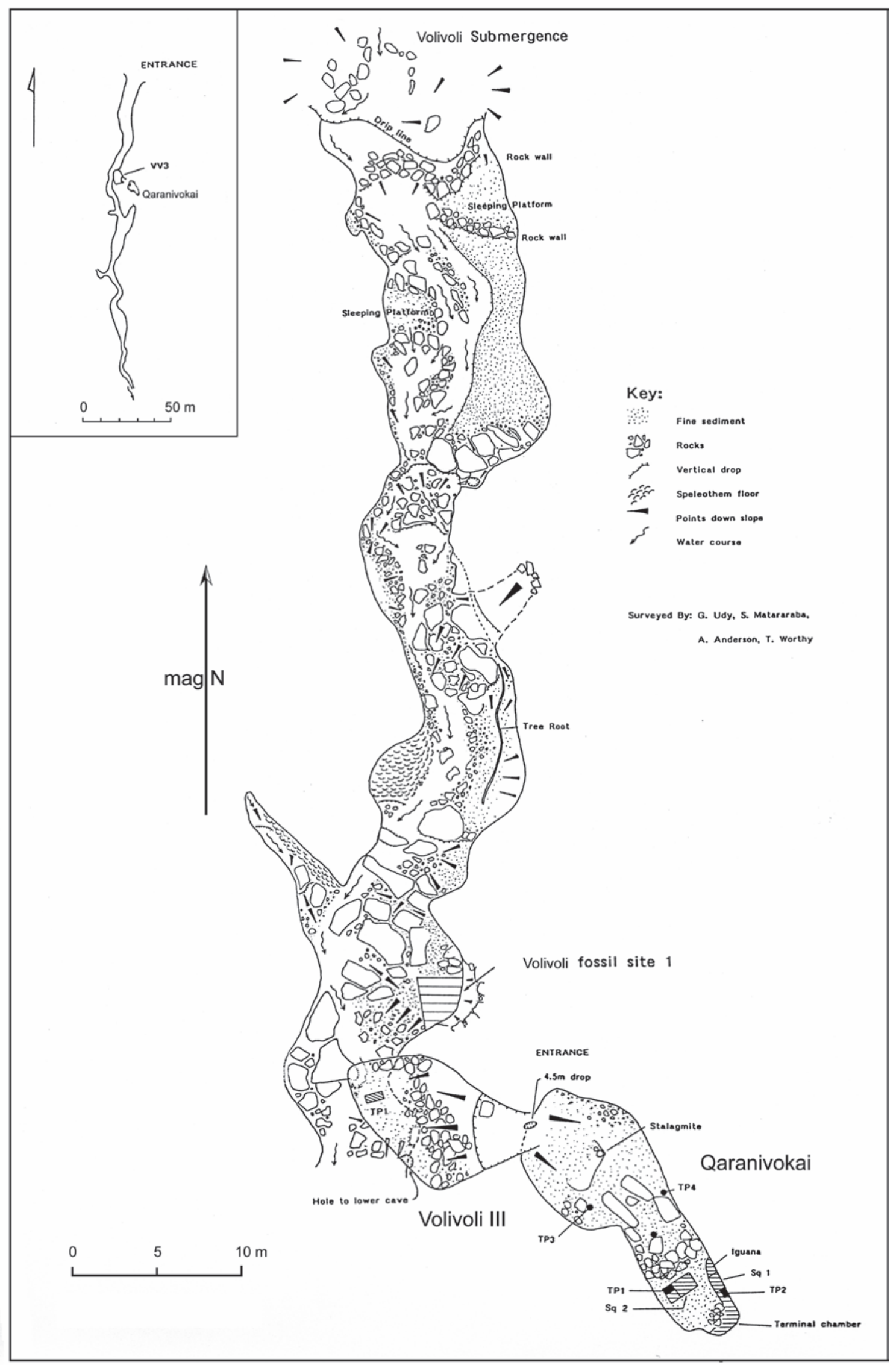

Figure 10. Volivoli Cave system, showing the location of Volivoli Ill, the newly discovered cave Qaranivokai and the test pits excavated in it, and Volivoli fossil site 1. 
dating of the bones was not possible. Preliminary optically stimulated luminescent dates from Volivoli Cave indicate an age of 10,000-20,000 years ago for the fossiliferous clay (Anderson et al. 2001).

Species recovered from the site include notably a crocodilian, a tortoise, a giant iguana (Lapitiguana), a boid snake, three species of frog (Platymantis spp.) and several birds, including a previously unknown giant megapode (Megavitiornis) and giant pigeon (Natunaornis).

\section{Qaranivokai}

On the entrance slope leading into Volivoli III, a small slot leads down a vertical drop of about $5 \mathrm{~m}$ into a $15 \mathrm{~m}$ long and $4 \mathrm{~m}$ wide chamber (Figure 10). We first entered this site on $26 \mathrm{March}$ 1998 and were the first people in it. Remains of a giant iguana skeleton were found on the surface near the end, and on its account, we named the cave Qaranivokai (cave of the iguana).

The deposits in Qaranivokai differ greatly from those in VV1 in the cave below. The sediment has washed into the cave via the entrance slot where a talus cone has built up. Test pits at several spots in the passage (Figure 10) showed a similar stratigraphy of a surface layer 20-30 $\mathrm{cm}$ thick that contains bones. This layer comprises fine brown unconsolidated silt that readily passes dry through a sieve. In the terminal chamber, the fossiliferous loam is deeper, extending to $46 \mathrm{~cm}$, but below this, as shown in a test pit excavated to $1.5 \mathrm{~m}$ depth (Figure 11), are several layers of dark material assumed to be derived from swiftlet guano. The age of the Qaranivokai fossil deposit was estimated to be mid-Holocene, as the absence of pottery and charcoal shows that it antedates the arrival of people in the area, and hence it must be older than about 3000 years BP. U-series ages of overlying speleothems in the terminal chamber clearly indicate that deposition had ceased there by about 4500 BP (Anderson et al. 2001). Two fossil bones, one a shaft of a femur from the iguana skeleton found on the surface, and the other a piece of iguana humerus collected from the surface of the terminal chamber, both approximately $5 \mathrm{~g}$ in weight, did not yield separable collagen and so could not be directly radiocarbon dated. However, radiocarbon dates on sediment presumed to derive from guano and fine charcoal fragments from the sediments enclosing the fossils suggest a Conventional Radiocarbon Age of

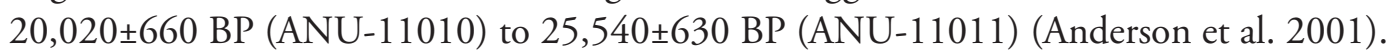

Compacted red/brown loam, subaerial
Red/brown friable loam, depth varies $10-25 \mathrm{~cm}$
Inclusions white microcrystalline calcite
Red/brown loam
Bine brown silts lack layer

Figure 11. Stratigraphy of Test Pit 1, Qaranivokai. 
We excavated areas of the final chamber as shown in Figure 10. Sediment was dry-sieved through a $6 \mathrm{~mm}$ mesh. Slight dampness of the silt made it impossible to put it through a $2 \mathrm{~mm}$ mesh and no water was available in the area. However, the presence of few stones and no shell made recovery of bone relatively easy and many small pieces were obtained. The fauna includes 15 species of bird, including the giant pigeon, three frogs, giant iguana and banded iguana, two types of bat, two species of gecko and a skink.

\section{Volivoli Swamp owl site}

On 3 April 1998, we surveyed the bluffs along the eastern escarpment of the Volivoli limestone block and found no further cave features. However, at the foot of the slope, beside the swamp which separates the escarpment from Volivoli village, an owl midden was found in an alcove on a boulder just above winter water level. A small sample from this revealed an interesting fauna, including fish bones indicating the owl responsible foraged over the wetland.

\section{Bukusia, Raiwaqa village}

Location: L28 c. 776846; edition 1, 1992. Visit: 5 June 1997.

The cave system is in a small, forested limestone hill. The grid reference given above is for the resurgence cave at the foot of imposing overhanging bluffs, and is about $100 \mathrm{~m}$ up a side stream of the river in the valley. However, the resurgence cave is only passable for about $30 \mathrm{~m}$ before it ends in a room with a skylight more than $30 \mathrm{~m}$ overhead. The stream emerges from an impenetrable passage. A colony of swiftlets (Collocalia spodiopygia) has deposited much guano in the final chamber, but beneath the skylight are some wall-like man-made structures, and a huge mound of midden material.

Exploration overland northwards from the resurgence revealed a shelter high up the hillside at the head of a steep rocky gully. From this shelter, a small crawl-way led off into a series of chambers with about 200-300 m of passages, some up to $20 \mathrm{~m}$ wide. These intersected several large skylights from the 'plateau' above and so had large quantities of freshwater mussel-shell midden with broken pottery in them. Charcoal figures were drawn on the walls in one place. One chamber allowed access to the plateau above and a very well-preserved hill fort - the single point of access from above ground, at one end still had a more or less complete wall across it. This hill fort is presumed to date from the Kai Colo uprising of 1875-76, having been built by Kunatui and his people after they were evicted from Tavuni.

Archaeological deposits were abundant all around the plateau and under all skylights within the cave. In places, heaps of midden were metres thick, but no bones were visible in them. All pottery sherds inspected were undecorated. Although no sediments containing fossils were found, two bones of the giant iguana were found on the surface at the small, eastern crawl-way entrance. Under the cliffs south of the resurgence were abundant bones beneath a barn-owl roost. This bone deposit was no more than $10 \mathrm{~cm}$ deep and overlaid up to $50 \mathrm{~cm}$ of cultural sediments, as indicated by charcoal, midden shells and pottery sherds.

\section{Sites near Toga village: Naihehe Cave}

Location: M28 812906; edition 1, 1993. Visit: 7 June 1997.

Naihehe Cave is at the eastern end of the impressive limestone cliffs backing Toga. It is a resurgence cave well known to the village, and is used as a tourist cave. A low roof at the entrance opens into large caverns that extend about $150 \mathrm{~m}$ from the entrance. At this point the stream emerges from a flooded passage. Along the true left side of the passage, ledges are present 
that slope upwards and appear to have been formed by solution upwards along the limestone bedding planes, suggesting a phreatic origin for the cave. We climbed up to most of the higher ledges seen along the cave.

The only fossils found were bat bones in a series of old rimstone pools. Many bones of the fruit bat Notopteris macdonaldi were present. In the Sigatoka Valley, the only known colony of this bat is in Tatuba Cave near Saweni. A few bones of the small sheath-tailed bat (Emballonura semicaudata) were also found.

\section{Tavuni owl site}

Location: L28 776905; edition 1, 1992 (17o 59' 17"S, 1770 35' 326"E). Visit: 7 June 1997.

At the western end of the limestone bluffs and west of Vunaivilela Creek under an almost vertical cliff some $200 \mathrm{~m}$ high, known as Naqalimare, is a small resurgence used as the water supply for Toga village. Barn owls nest in the cave above the water supply and a large downy chick was present on our visit. About $20 \mathrm{~m}$ along the cliff from the resurgence cave, a slot leads into a round room of about $3 \mathrm{~m}$ diameter, which is essentially the base of a shaft rising up into the cliff. Owl midden debris was on the floor.

A test excavation $60 \mathrm{~cm}^{2}$ to a depth of $125 \mathrm{~cm}$ was made on the side of the round room nearest to the spring. Its stratigraphy was as follows: Layer $1,0-2 \mathrm{~cm}-$ unconsolidated dust with owl midden bones; Layer 2, 2-7 cm - fluvial silts; Layer 3, 7-90 cm - black loam (paddleimpressed pottery at $60-70 \mathrm{~cm}$, layer of limestone rocks at 40-60 cm; Layer 4, 90-100 cm - grey-black loam, many fragments limestone; Layer 5, 100-125 cm - patches of red earth in grey soil, no bones.

Sediment samples were taken at 30, 45, 60 and $90 \mathrm{~cm}$ (now at ANU). Most bones were rats, which were common to $35 \mathrm{~cm}$, sparse between 35 and $45 \mathrm{~cm}$, and absent below $45 \mathrm{~cm}$. On the surface, bones of Rattus rattus were present, but most on the surface and all those to 35 $\mathrm{cm}$ were $R$. exulans. Some of the deepest specimens were $R$. praetor. The owl midden was only a surface feature, no more than $10 \mathrm{~cm}$ deep.

\section{Vunaivilelu Creek, Naqalimare - Mt Koroiemalu}

Location: South of the road between the Tavuni site and Toga village. Detailed locations given below. Visits: 9-10 June and 28-29 September 1997.

The dry bed of Vunaivilelu Creek was searched for caves along the flanks of the huge limestone bluffs of Naqalimare. No fossil deposits were found. However, in the area to the south of $\mathrm{Mt}$ Koroiemalu, at the head of Valivali Creek, we found cavernous limestone and a few caves.

\section{Koroiemalu Cave}

Location: 17o 59' 31"S, 177o 36' 36"E.

The major cave, which we named Koroiemalu Cave, has three entrances in grassland near the base of a small valley leading towards the back of the forested Mt Koroiemalu. One of the entrances is a $15 \mathrm{~m}$ shaft, and the other two may be climbed into. We explored about $200 \mathrm{~m}$ of passages but were stopped by a $6 \mathrm{~m}$ deep shaft needing tackle. Although our 'guides' did not know of the cave, charcoal symbols on the walls were evidence of previous visitors. No fossiliferous deposits were found and the clean-washed nature of the passage attests to seasonal flushing of the cave. A nearby cave led from the end of a valley in tall bamboo, down an impressive $35 \mathrm{~m}$ deep shaft, but there it ended. Across the top of the pitch, $10 \mathrm{~m}$ of guanorich passage also had no fossils. 


\section{Tatuba Cave - Saweni and environs}

Location: The resurgence entrance is at M28 992004; edition 1, 1993; the hill above the cave is at: 17o 54' 02"S, 1770 47' 56"E. Visits: 12-13 June and 29 September 1997.

Tatuba Cave is one of the best-known caves in the Sigatoka Valley (Gilbert 1984) and has an impressive wall across its lower entrance. Large numbers of swiftlets inside the cave have built up huge piles of sediment. At one point is a roost of the fruit bat Notopteris macdonaldi. Sediments below the present bat roost are highly acidic and so bones are rapidly dissolved - even those few on the surface were essentially destroyed. We searched all surfaces in the cave and only a very few bat and swiftlet bones were found. It is improbable that any fossiliferous sediment is present in these upper levels of the cave as a result of the leaching caused by the guano. At the upstream end of the cave are three further entrances, beneath which lie abundant undecorated pottery sherds and other archaeological debris. No bone deposits were found. In the surrounding large depression, seven other cave entrances were located (Figure 12). These are:

No. 1. This appeared to be an excellent pitfall trap. A $2 \mathrm{~m}$ drop to a ledge was followed by a further $4 \mathrm{~m}$ pitch to a floor. A test pit revealed clay containing worked stone and pottery to $50 \mathrm{~cm}$ depth, where apparent bedrock was encountered. Therefore, all sediment is of posthuman age.

No. 2. A deep $30 \mathrm{~m}$ doline had an impenetrable water sink on one side, but on the other, a partly walled-up small hole led to $15 \mathrm{~m}$ shaft. At its base, parts of at least five human skeletons were partly buried by washed-in clay. The bones were completely decalcified. While the floor looked suitable for fossils, none were seen, and all sediments are probably very recent.

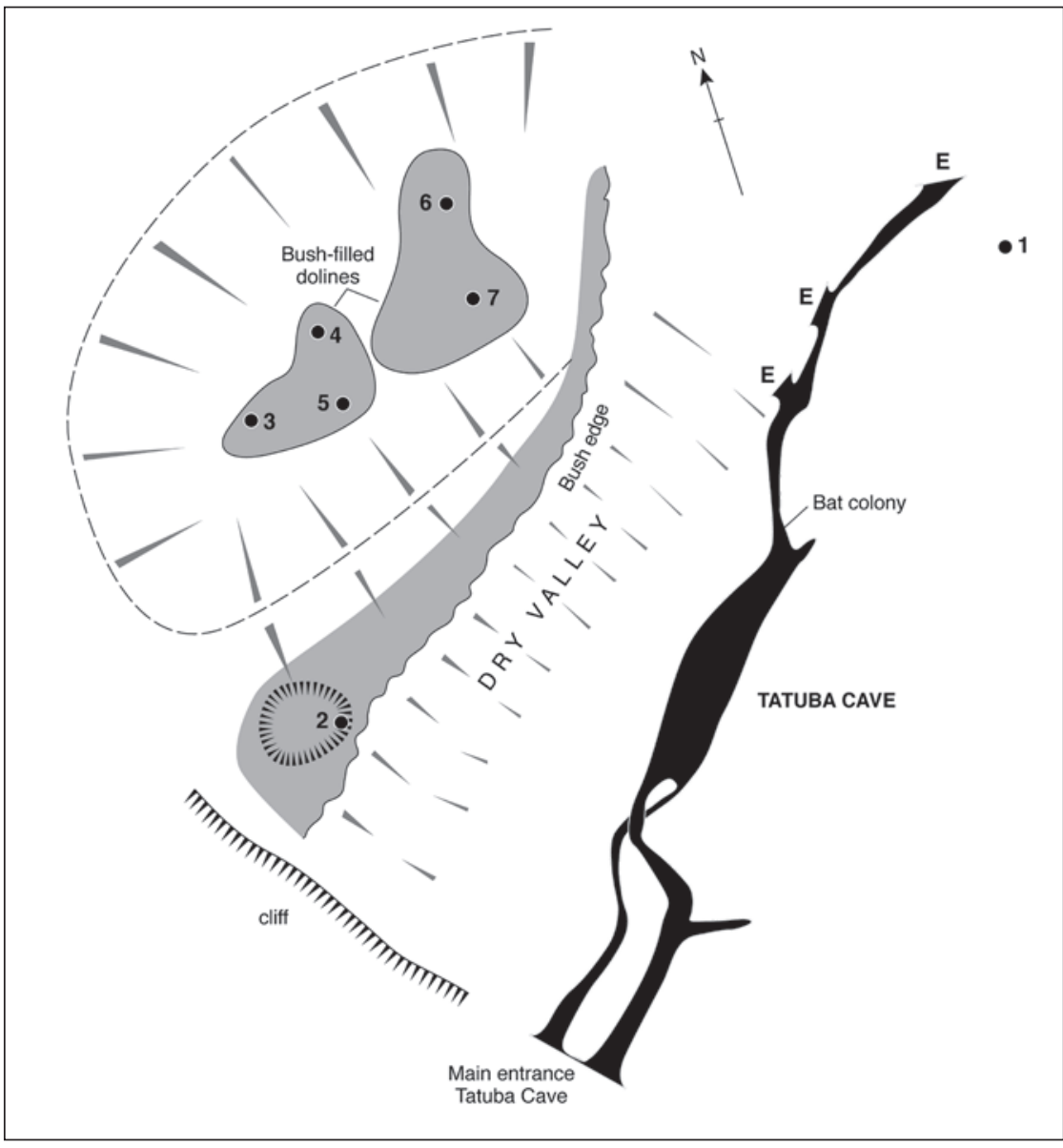

Figure 12. The Tatuba Cave system and the location of other cave features (1-7) described in the text. Cave map is after Gilbert (1984). 
No. 3. A shaft with $3 \mathrm{~m}, 4 \mathrm{~m}$, and $7 \mathrm{~m}$ steps led to a terminal room with clay deposits all over the walls, which obviously floods seasonally, and had no fossils.

No. 4. At the upper end of the doline containing sites 3 and 5, a slot opens to drops of $5 \mathrm{~m}$ then $6 \mathrm{~m}$ followed by a narrow rift, then another $8 \mathrm{~m}$ pitch to a narrow passage; no fossils.

No. 5. A $5 \mathrm{~m}$ diameter shaft about $4 \mathrm{~m}$ deep. On the upper side, a cave led in about $6 \mathrm{~m}$ and contained one burial. Sparse remains of owl midden were present. Downslope, a crawl led into a well-washed cave about $15 \mathrm{~m}$ long, with no fossils.

No. 6. A small $6 \mathrm{~m}$ deep shaft with much flowstone on its walls, but no fossils.

No. 7. A small water sink, with an unexamined shaft.

Our general impression was that run-off from surrounding land has mobilised lots of sediment, filling these caves with sediment in the past 1000-2000 years. As the run-off is from non-limestone substrates, it is acidic and would soon dissolve any bones that might have been there. As a result, there appears to be little potential here for fossils.

\section{Tuvu}

Location: The chief's house on the old village site at the north end of the limestone hill affords the most direct access. It is at: 170 55' 52"S, 1770 42' 18"E; grid reference M28 892969; edition 1, 1993. Visits: 17 June 1997 and 31 March 1998.

The limestone hill at Tuvu is about $1 \mathrm{~km}$ long and a little narrower. The road passes along the eastern boundary of the hill, enabling ready access to it. Apart from the well-known burial cave on the eastern flanks of the hill (Gilbert 1984), several other features were found (Figure 13). Near the top of the hill (about M28 890966), a large collapsed canyon feature can be followed roughly northwest. In it, many crevices lead deep underground, but the rocks were very unstable. Despite examination of several rooms and chambers well out of daylight, no fossil

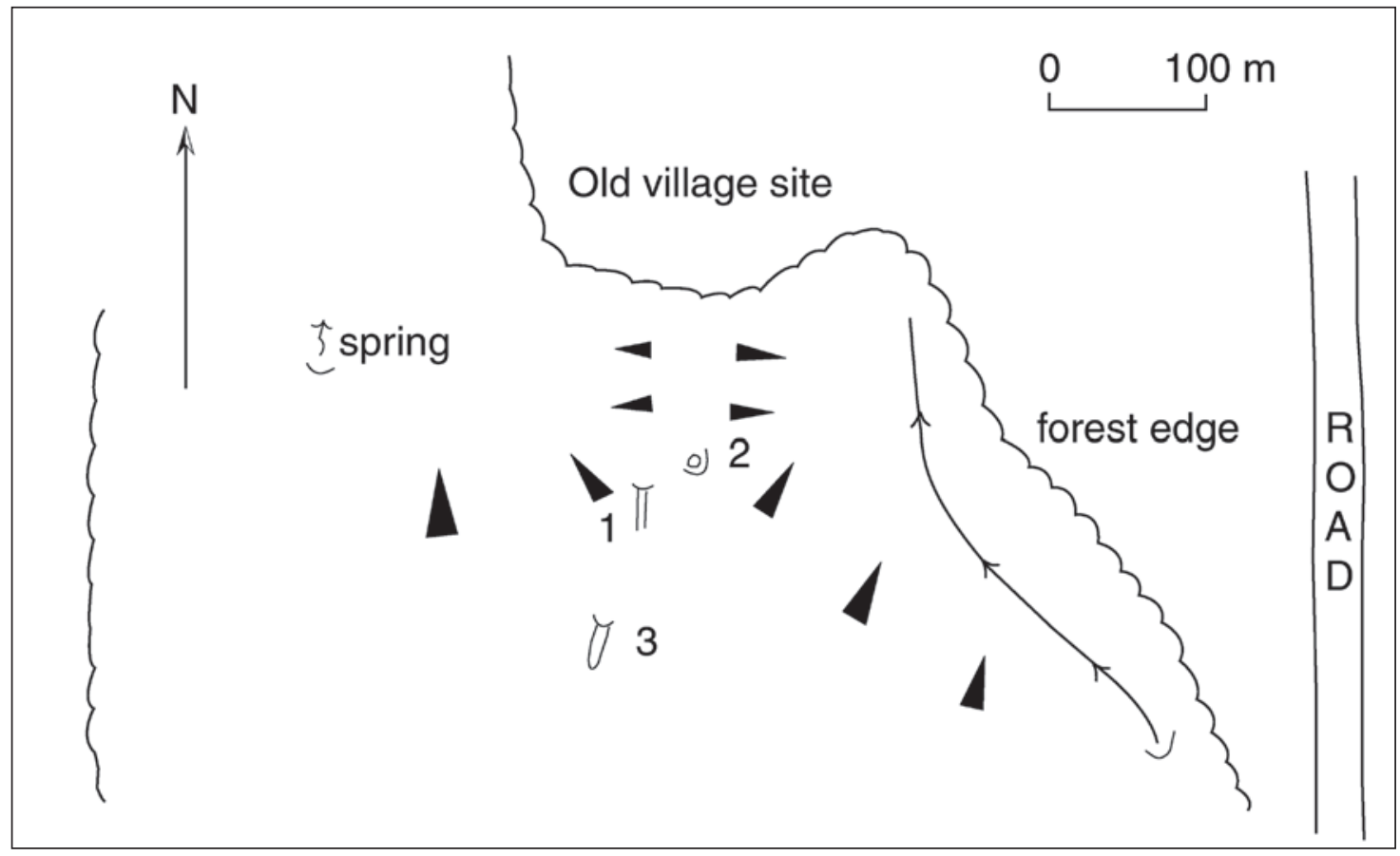

Figure 13. The location of caves (1-3) investigated at Tuvu. 
bones were found. We think the instability of the caves and fissures means that all 'floors' are of very recent age. On the north side of the outcrop, immediately south of the old village site, are three caves:

No. 1. About $30 \mathrm{~m}$ in from the forest edge and just on the west side of a low ridge running off the limestone towards the village site is a small horizontal cave. This had many human bones in it, and was not explored.

No. 2. A few metres from No. 1, a shaft drops about 7-8 $\mathrm{m}$ down into a small cave. A few human bones were on the floor at the base of the shaft, but despite the cave's promising location, no fossil deposits were found. Much of the floor floods seasonally.

No. 3. About $70 \mathrm{~m}$ up the hill above the two caves described above is a solution cave about $5 \mathrm{~m}$ high, 2-6 $\mathrm{m}$ wide and $15 \mathrm{~m}$ long.

In No. 3, there was a low entrance to a back chamber of the cave, probably a burial chamber. It was partially walled in and was not investigated. A small colony of swiftlets inhabited the cave on our visit. In the front chamber, a test pit $0.8 \times 0.5 \mathrm{~m}$ was excavated in $10 \mathrm{~cm}$ spits. The stratigraphy disclosed was as follows: Layer 1 Spit 1 , a soft grey silt containing pottery sherds. Spit 2 was largely occupied by a soft, lensed white ash or calcite. Layer 2 Spits 3-5, a grey-brown silt containing a few shells, pottery sherds and some charcoal, with weakly defined lenses, but no layering. Layer 3, excavated to $105 \mathrm{~cm}$ depth, consisted of soft, orange-brown silt, probably originating in guano. It contained no cultural material and continued beyond spade depth at approximately $150 \mathrm{~cm}$. Lack of an entrapment mechanism makes this an unpromising site for fossils.

\section{Fossil sites in Tau district}

Location: L28 455917; edition 1, 1992; near 17o 58' 29"S, 177o 17' 18"E. Visit: 30 March 1998.

This, the westernmost cave site examined, is about $3 \mathrm{~km}$ from the coast. A small area of limestone outcrops on the hill above Tau village and near the top of a forested gully on the outcrop at about $200 \mathrm{~m}$ above sea level contains a large cave called Qaranioso \#1. Gilbert (1984) did not record this cave. It opens from an entrance about $4 \mathrm{~m}$ wide and $6 \mathrm{~m}$ high into a large chamber some $15 \mathrm{~m}$ wide and $30+\mathrm{m}$ high (Figure 14). Skylights in the roof allow light into this chamber, but a voluminous $60 \mathrm{~m}$ long cavern extends from here to the north, and is completely in the dark. On our visit, there was a large colony of swiftlets. The villagers informed us that many years before, people had mined the guano from the cave, and that at one stage a fire had burned within it for many days. About $25 \mathrm{~m}$ from the mouth of the cave, downhill to the northwest, is a large rock shelter, or remnant cave chamber entering the side of the hill, which we termed Qaranioso \#2.

At the mouth of Qaranioso \#1 are remnants of flowstone deposits and calcified infill breccias that are likely to be some of the oldest cave deposits found in Fiji. On the sloping floor, just inside the entrance, are remnant archaeological deposits that in an exposed section appear to be up to $0.5 \mathrm{~m}$ deep. Some $30 \mathrm{~m}$ into the cave, on the level floor at the start of the big cavern, there are extensive surface scatters of midden and pottery sherds. At the break of slope into the cave a section was cut to record the stratigraphy (below). Sediments from fallen debris, originating from the skylights, slope down to the base of the first chamber, and no fossils were evident. The floor of the final chamber is covered in guano in piles up to $10 \mathrm{~m}$ high. 


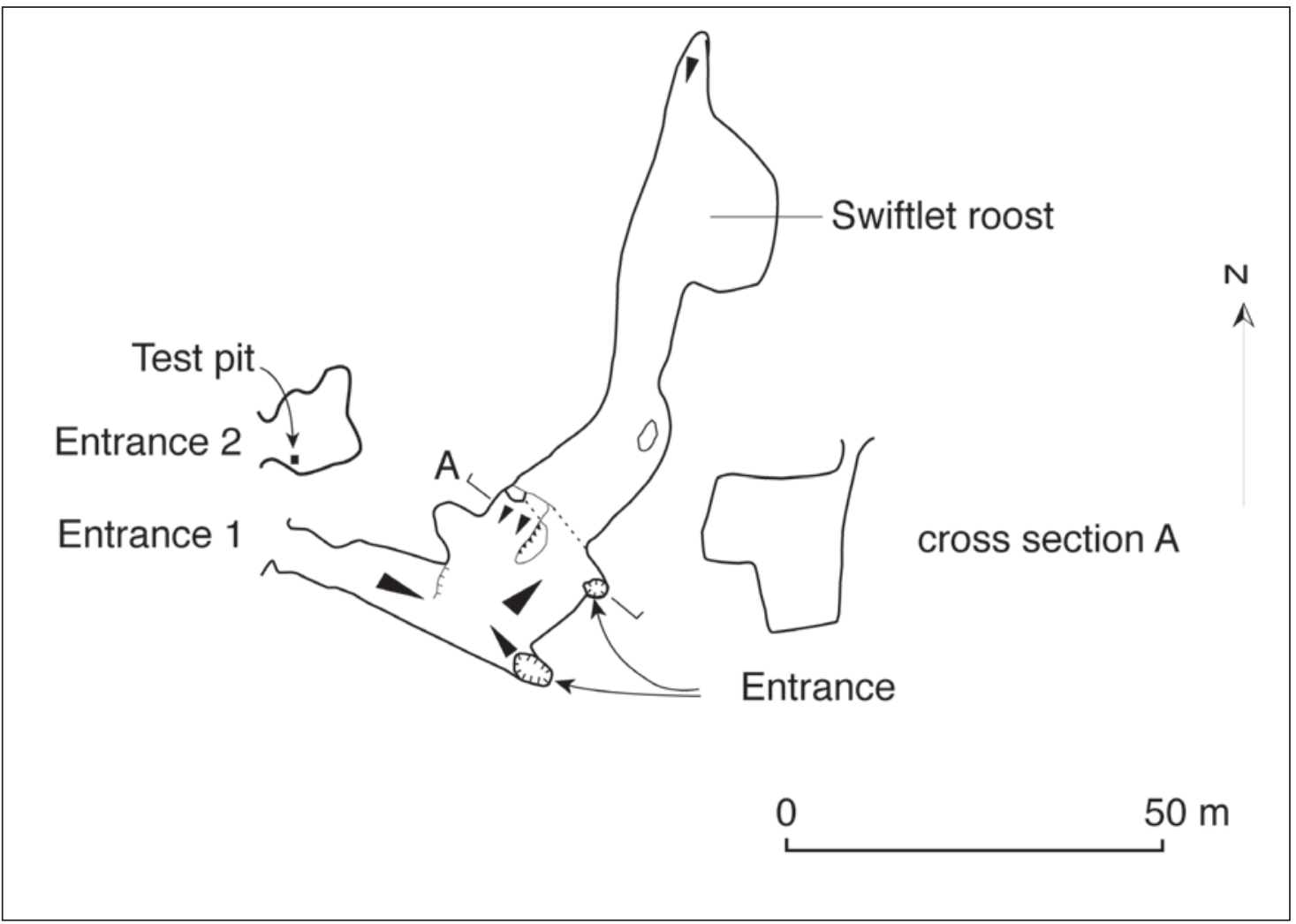

Figure 14. Plan of the cave Qaranioso, Tau, showing the location of the test pit.

Qaranioso \#2 is a largely flat-floored chamber that is dry, and throughout which light penetrates. Much of the floor was covered in owl-midden debris, but towards the entrance, archaeological midden was evident. A test pit was excavated (see Chapter 3).

\section{Sites inland of Nadi: Nabalabalagita Cave}

Location: Near Nawaqadamu village (17 55' 44.3"S, 177² 25' 45.6"E; L28 601969). Visit: 16 November 1999.

This is a small rock shelter $4 \mathrm{~m}$ wide at the entrance by $6.5 \mathrm{~m}$ long. A test pit $(50 \times 50 \mathrm{~cm})$ was excavated to basement limestone at $62 \mathrm{~cm}$ depth. Layer $1(0-2 \mathrm{~cm})$ was loose brown sediment, rich in bones from an owl midden. Layer $2(2-8 \mathrm{~cm})$ was ash and charcoal, with some midden shell. Layer $3(8-23 \mathrm{~cm})$ was brown sediment with charcoal, midden shell, abundant pottery and abundant bones of $R$. exulans. Layer $4(23-38 \mathrm{~cm})$ was red, compacted lateritic clay sediments containing a lens of ash in the top $5 \mathrm{~cm}$ of the layer. Rat bones $(R$. exulans) were present. Layer $5(38-62 \mathrm{~cm}$, base) was a friable organic soil. Only the top $5 \mathrm{~cm}$ of this layer, which was more organic and compacted, had rat bones in it. The lower part of the layer was less dark, more friable and lacked rats entirely. However, pottery sherds, some decorated, midden shell and some unidentified large bird bone fragments were in the lower layer. The paddle-impressed pottery sherds were at $55 \mathrm{~cm}$ depth.

The sequence suggests the site was under forest and contained organic rich (forest-derived) soils when people first used the cave, and notably indicates that people arrived before owls if it is assumed the onset of rat-bone deposition marked owl arrival. The marked change in sedimentation indicated by the onset of deposition of red sediment suggests forest clearance and presumed gardening activities on the slopes above the cave at that time. Then after an unknown 
period, sedimentation in the cave changed to conditions more like those at present, except that people camped regularly in it. The surface of the site was covered in an owl midden from which a sample yielded fauna.

\section{Outcrop of limestone at L28 609984}

The hard crystalline limestone of this outcrop was explored for caves and fossil deposits on 17 November 1999. The limestone is very fractured with well-developed karren on the surface. Some of the fractures contained lithified fissure-fill sediments (breccias) of red earth and basalt gravels with Placostylus and other land snails incorporated in them. A cave, formed by fracturing of the outcrop, was explored to about $40 \mathrm{~m}$ below the entrances in the top of the outcrop. Swiftlets lived in it. Extensive examination of this cave failed to find any fossiliferous sediments, but in an exposure of the hard (probably Pleistocene) breccias, a single bone of the extinct frog Platymantis megabotoniviti was found.

\section{Vatumu}

Location: About $7 \mathrm{~km}$ north of the hill site described above at $17^{\circ} 52^{\prime} 56.9^{\prime \prime S}, 177^{\circ} 28^{\prime} 29.0^{\prime \prime} \mathrm{E}$; L28 647020. Visit: 18 November 1999.

The limestone outcrop is small and had a fort constructed on it at one time. There are at least two cave features, but the most obvious is a large entrance in the west side of the outcrop that immediately opens to a $10 \mathrm{~m}$ pitch to the floor of a chamber $5 \mathrm{~m}$ wide by about $15 \mathrm{~m}$ long. A test pit showed the floor of the chamber has been filled in by rocks for at least $1 \mathrm{~m}$ depth: they overlay fine silts derived from swiftlet guano.

The cave has unconsolidated sediment infill in several places with archaeological materials incorporated in them, e.g. midden shells and pottery sherds, and one side passage has a human burial in it. A single fossil site was located in an alcove below the entrance pitch. Bones were incorporated in consolidated clays, which lacked charcoal and pottery sherds and so are assumed to be of prehuman age. The fragmented nature of the bones and species present in the fauna suggests they may derive from falcon prey. The fauna included the extinct frog Platymantis megabotoniviti, an extinct Ducula, an extinct snipe (Coenocorypha miratropica), a duck and two petrel species.

\section{Sites in eastern Viti Levu: Wainibuku area}

There are a number of described caves in the southeastern region of Viti Levu (Gilbert 1984). The descriptions of geologically young, small caves, with active streamways at, for example, Quaia, Kalabo and Lami, give little hope that fossiliferous sediments would be present in them. In contrast, the more extensive karst area centred on the Wainibuku Valley has several more extensive caves with some passages now abandoned by the streams that made them. This fact and the fact that all had more than one entrance made them potential fossiliferous sites. Here, caves are referred to by the names given by Gilbert (1984), who described and mapped them. Figure 15 is adapted from Gilbert (1984:Figure 8) and shows the relationships between the various caves.

\section{Wainibuku Cave}

Location: O28 722827; edition 1, 1990; resurgence at 18 03' 36.7"S, 178 29' 11.4"E. Visits: 1, 2, 6 and 7 October 1998; 23 November 1999. 
This is the cave referred to as Bureivulu Caves by J. Koroikata. The cave is owned by Mr Dharam Singh. The entrance to the main cave is a resurgence which debouches into a deep round pool of water in a small forested valley beside the vehicle track (Figure 15). Two other cave entrances are also found here. About $30 \mathrm{~m}$ from the pool, the access track passes an entrance to a smaller cave that is about $4 \mathrm{~m}$ high and $1.5 \mathrm{~m}$ wide. About $20 \mathrm{~m}$ inside the cave, the passage forks. Straight on leads, after about $20 \mathrm{~m}$, to a rockfall that terminates progress. Bones of the bat Notopteris were present on the floor and in sediment between the rocks here. The other passage branch leads after about $40 \mathrm{~m}$ to another rockfall that also blocks the cave. Again, a few bat bones were present on the floor. The second cave is about $4 \mathrm{~m}$ to the true right of the main cave entrance, and is accessed by a traverse above the pool. This leads to about $40 \mathrm{~m}$ of passage that gets progressively narrower. Some sediment is present on the floor, but no bones were noticed.

The main cave is initially $10 \mathrm{~m}$ high and $4 \mathrm{~m}$ wide. The stream is present in a narrower canyon incised in the floor and progress is along ledges above it. The cave is notable for the large numbers of swiftlets living/nesting in it. The cave is about $200 \mathrm{~m}$ in length and comes from an upstream submergence entrance. We did not investigate the upstream third of the passage, which has deep water. About $120 \mathrm{~m}$ upstream of the resurgence there is a side passage on the true right that extends about $30 \mathrm{~m}$. Roosting in the roof of this passage were thousands of individuals of the fruit bat Notopteris macdonaldi.

On the floor of this side passage, in the last $15 \mathrm{~m}$, are pot-hole type erosion features formed by a former stream that are filled with alluvial sediments. The floor is covered in sloppy guano and non-flowing water sits in the pot holes. Upstream, the passage is terminated by a speleothem blockage, but it is assumed that the stream that formed the passage and deposited the sediment came from beyond this blockage. Fossils were located in the sediment in these pot holes. On the surface were numerous bones of Notopteris, but a few bones of the large frog P. megabotoniviti encouraged us to search more thoroughly. There were five pools and a few

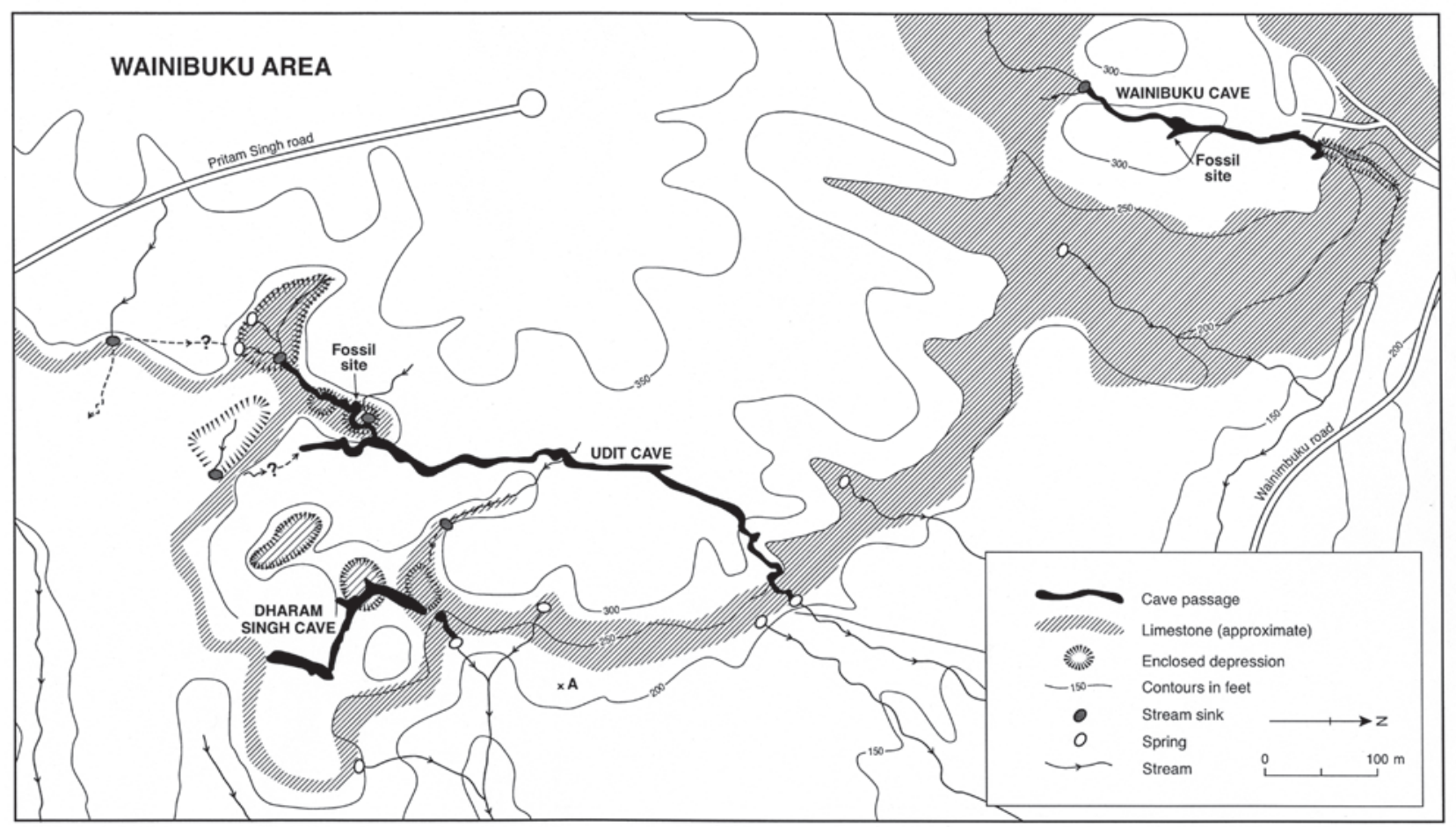

Figure 15. A plan of the caves in the Wainibuku area, after Gilbert (1984), showing local contours and stream drainages. 
metres of interconnecting trench. The fossiliferous sediment was wet-sieved in the nearby stream through a $5 \mathrm{~mm}$ mesh and the concentrate was sorted in laboratory conditions later.

Starting at the flowstone blockage, the deposit is as follows. A narrow (ca. 20-40 cm wide) and shallow $(<20 \mathrm{~cm})$ deposit of silts extends for about $4 \mathrm{~m}$ to the first pool. No bones were found in the sediment extending from the flowstone blockage. The first pool is about $80 \mathrm{~cm}$ wide and about $40 \mathrm{~cm}$ deep. Under a surface layer of silts about $20 \mathrm{~cm}$ thick is clay. Two fossils were found in the silts and none in the clay. From this point downstream the deposits are covered in wet, fresh guano a few centimetres deep. About $2 \mathrm{~m}$ 'downstream' over bare rock is a second pool of similar size which contained several fossils at the clay-silt interface. Another metre or so 'downstream' is a third pool about $1 \mathrm{~m}$ in diameter with few fossils, and then, after another $1 \mathrm{~m}$, is an elongated pool about $0.5 \mathrm{~m}$ wide and $2 \mathrm{~m}$ long. This feature is deeper, the silt layer is up to $30 \mathrm{~cm}$ thick and the clay extends to about $60 \mathrm{~cm}$ depth. Fossils were found in the silt and in the upper part of the clay layer.

The last deposit is a $1.5 \mathrm{~m}$ wide, shallow, circular pool just above a slope leading down to the present stream. Under the guano deposit, which is deepest at this point, is a layer $10 \mathrm{~cm}$ thick of sand, containing sticks and abundant bat bones (L1). About $5 \mathrm{~cm}$ of consolidated clay (L2) separates the next silt and sand layer (L3), which is also $5-10 \mathrm{~cm}$ deep. This layer contains many bones, all stained black, including boa vertebrae and crocodilian bones. A $15-20 \mathrm{~cm}$ layer of fine clay (L4) devoid of bones underlies this fossil layer. Then a layer (L5) about $10 \mathrm{~cm}$ thick, comprised of sloppy clay with a gritty texture and mudstone inclusions (equates to Layer 2 in the upper pools), contains fossils. Unlike the black bones encountered above, these are stained light brown and have dark brown concretions growing on them. Fine clay without fossils extends to the deepest point of the pool at a further $40 \mathrm{~cm}$ depth.

The black bones from the lowest pool show little evidence of stream transport and the crocodilian bones are from two individuals. However, many crocodilian teeth are from substantially larger animals than those represented by the bones. The bones in the lower, more clayey layer from all pools have the same preservation and were relatively stream worn by the time of their burial, indicating considerable lateral transport.

\section{Dharam Singh Cave}

Location: The most easily located entrance to Dharam Singh Cave is found on the slopes of an enclosed doline, about $40 \mathrm{~m}$ up to the true right of the short cave leading from it (Figure 15). The small cave is about $30 \mathrm{~m}$ long and carries a stream to a resurgence at a house at $18^{\circ} 03^{\prime}$ $54^{\prime \prime S}, 178^{\circ} 29^{\prime} 30^{\prime \prime} \mathrm{E}$, which is at the end of a vehicle track; shown as point A in Figure 15. Visit: 2 October 1998.

This cave is known as Tokorokolulu to the present (1998) leasee, Kemueli Vukeiono. It was not owned in 1998, and nor has it been owned by Mr Dharam Singh to our knowledge, so it is not known why Gilbert (1984) used this name for the cave.

A steep scramble down a slope leads into passages of impressive dimensions. To the north (left), the passage is $30-40 \mathrm{~m}$ wide and high, and extends nearly $100 \mathrm{~m}$ to a rockfall collapse. Southwards, the passage is smaller but still usually several metres wide. A large rockfall slopes upwards more than $50 \mathrm{~m}$ on the right close to the entrance. A narrow section where rockfall nearly blocks the passage leads to the final chamber that is $55 \mathrm{~m}$ long and $9 \mathrm{~m}$ wide and opens to the second, larger entrance. The northern limb of the cave has a floor with rockfall on it and the only fossils found were some Notopteris bones in a small deposit of consolidated sediment 
on one wall. Several bones of a chicken (Gallus gallus) were found at one point. The southern branch of the cave has flat, clay-covered floors over which water seasonally flows, and no fossils were found.

\section{Udit Cave}

Location: Udit Cave is the longest known cave in the Wainibuku area, with $790 \mathrm{~m}$ of passage (Gilbert 1984). It extends from depressions beside Pratam Singh Road to the resurgence in the Wainibuku Valley (Figure 15). Visits: 2, 3, 6 and 7 October 1998; 20 November 1999.

The upstream submergence is a low cave entrance $(<0.5 \mathrm{~m}$ high) beneath overhanging vegetation, into which a stream flows and into which much domestic rubbish unfortunately has been tipped. Inside the cave, the passage is $2-3 \mathrm{~m}$ wide and $1-2 \mathrm{~m}$ high, with abundant stalactites descending from the roof. Rubbish is wrapped around most rocks and stalactites where it has been left by floodwaters. We did not follow this passage to its end, but believe it to be blocked by rubbish about $100 \mathrm{~m}$ downstream.

The cave can be accessed via a doline about $150 \mathrm{~m}$ to the northeast. Here, a steep climb down one side of the doline allows eventual access to the stream. Upstream and downstream it is blocked by rubbish, so making impossible the traverse to the cave in either of the directions surveyed by Gilbert (1984). A dry cave entrance opens into the side of the doline and this was investigated. It is only about $4 \mathrm{~m}$ long and boulders rise up to the back of the cave. However a gap between the boulders leads to a small cavity at floor level where a fossil deposit was found, which we called the Udit Cave Pitfall site.

In the valley running northeast of the Udit Cave Pitfall site are two shafts. One is narrow and about $8 \mathrm{~m}$ deep and ends at the water level. The other is about $5 \mathrm{~m}$ deep and goes to a flat floor, $2 \mathrm{~m}$ wide by $5 \mathrm{~m}$ long. No fossil deposits were found in them. The resurgence of Udit Cave has a weir built across the stream and the inhabitants of the local houses use the water. We entered the cave here and climbed the $6 \mathrm{~m}$ waterfall blocking access and explored upstream 500-600 m through the rest of the cave. Gravel deposits are present in several parts of the upper reaches of the cave but none of these were found to contain any fossil bones. The rubbishchoked connection to the doline with the Udit Cave Pitfall site in it was located.

\section{Udit Cave Pitfall site}

Location: O28; edition 1, 1990; 18º 04' 02.6"S, 178 29' 21.0"E.

The deposit in this site is very small and initially was probably $1 \mathrm{~m}$ long by $0.5 \mathrm{~m}$ wide and 30 $\mathrm{cm}$ deep. The site is confined, with walls about $0.5 \mathrm{~m}$ apart and the working space about $1 \mathrm{~m}$ long. The deposit is visible initially as bones loose on the floor and a cross-section of cobbles capped with flowstone about $30 \mathrm{~cm}$ above the floor. The visible deposit on the floor is thus a lag derived from erosion of the primary deposit by dripping water. The sediment was excavated by trowel and passed outside for processing. The primary deposit was found to be in situ on the inner side of the 'chamber' and some articulated elements were recovered. The sediment is wet clay. Once the floor was excavated to about $25 \mathrm{~cm}$, a low passage was found extending upstream, in which perennial water flow was apparent. The fossil material seems to have had its source somewhere upstream and to have been washed downstream to the site where it accumulated in sediment against the rockfall. A speleothem sample was obtained, but the crystal structure is too contaminated by silt for uranium series dating. Bone samples from the deposit lack preserved collagen, so are unsuitable for radiocarbon dating. 


\section{Wailotua Cave}

Location: West (main) entrance O27 638157; edition 1, 1993; east entrance O27 644157; edition 1, 1993. Visits: 5 October 1998 and 24 November 1999.

This is the longest cave in Viti Levu, with about $1500 \mathrm{~m}$ of passage mapped by Gilbert (1984). Entry is usually via the fossil resurgence or western entrance beside Wailotua village, and the large passages are easily traversed. The eastern end is preceded by a huge cavern with myriads of swiftlets and bats in it, notably Notopteris macdonaldi, but possibly also including Emballonura. The floor of this cavern has seen extensive guano mining and the floor of the cave from here to the western entrance has been modified to allow a small railway to transport the material. Sediments throughout most of the cave are cobbles and sands deposited by the precursor of the present large stream that enters the eastern entrance and disappears down passages to the northwest. The high energy of this stream and the modifications caused by the mining make it unlikely that any fossiliferous sediment is present and none was found. In the main chamber, on what is labelled the Terrace, the sediments forming this feature appear to be of colluvial nature and lack bedding and lack the rounded nature of stream-transported sediments. Despite several extensive cross-sections of these sediments being available for examination, not a single fossil was found.

\section{Delaniqara}

This cave is on the top of the hill above Wailotua Cave and is unmapped. It was not completely explored by us. Access is via a $4-5 \mathrm{~m}$ diameter pitfall entrance down a steep climb into a large cavern, which leads down between giant blocks of rock to successively lower levels. The upper regions are characterised by extensive deposits of flowstone covering all floor surfaces, and in most places such floors are composed of boulders. Large colonies of swiftlets and bats (Notopteris macdonaldi) were present in 1998 and in 1999.

Substantial areas of the cave were explored, but apart from numerous bat bones, we only located two fossil specimens - a part skeleton of the giant megapode Megavitiornis altirostris in October 1998 and a rail (Nesoclopeus poicilopterus) in November 1999. Numerous bat and swift bones litter the floors of many chambers. The extensive flowstone deposits make detection of an old surface on or in which fossils might be found difficult.

\section{Fossil sites on Vatulele Island}

Vatulele is a small island about $30 \mathrm{~km}$ south of Viti Levu, some $12.9 \mathrm{~km}$ long north to south, and with a maximum width of $4.9 \mathrm{~km}$ in the north (Figure 16). It has greatest elevations above sea level along the western coast, with a maximum of $38 \mathrm{~m}$ in the northwest, but is generally much lower. Thin soils formed on limestone, or limestone rock, cover most of the ground surface on the western plateaus and slopes above a few metres altitude. Along the eastern coast, narrow sand dunes enclose a low-lying, marshy area, with deep latosolic soils. Inland of these are well-drained inland flats with thin soils (Nunn 1988). Most of the marshy areas are modified by gardening or by coconut plantations.

Near the coast in the more elevated northern and western parts of the island, the limestone is extensively eroded into a makatea landform - a sharply eroded karst typical of tropical coastal limestone and usually of reefal limestone. Caves are numerous but large features are few. None are mapped, but my observations suggest that the larger ones (Muremure, Big Cave) developed at the water table where freshwater was concentrated in a route that drained the central and eastern parts of the island towards the coast. This is likely to have occurred when sea levels were as much as $120 \mathrm{~m}$ lower during the last glacial period of the Pleistocene when the present eastern lowlands and lagoons with their sandy basements might have been wetlands. Big Cave, at least, 


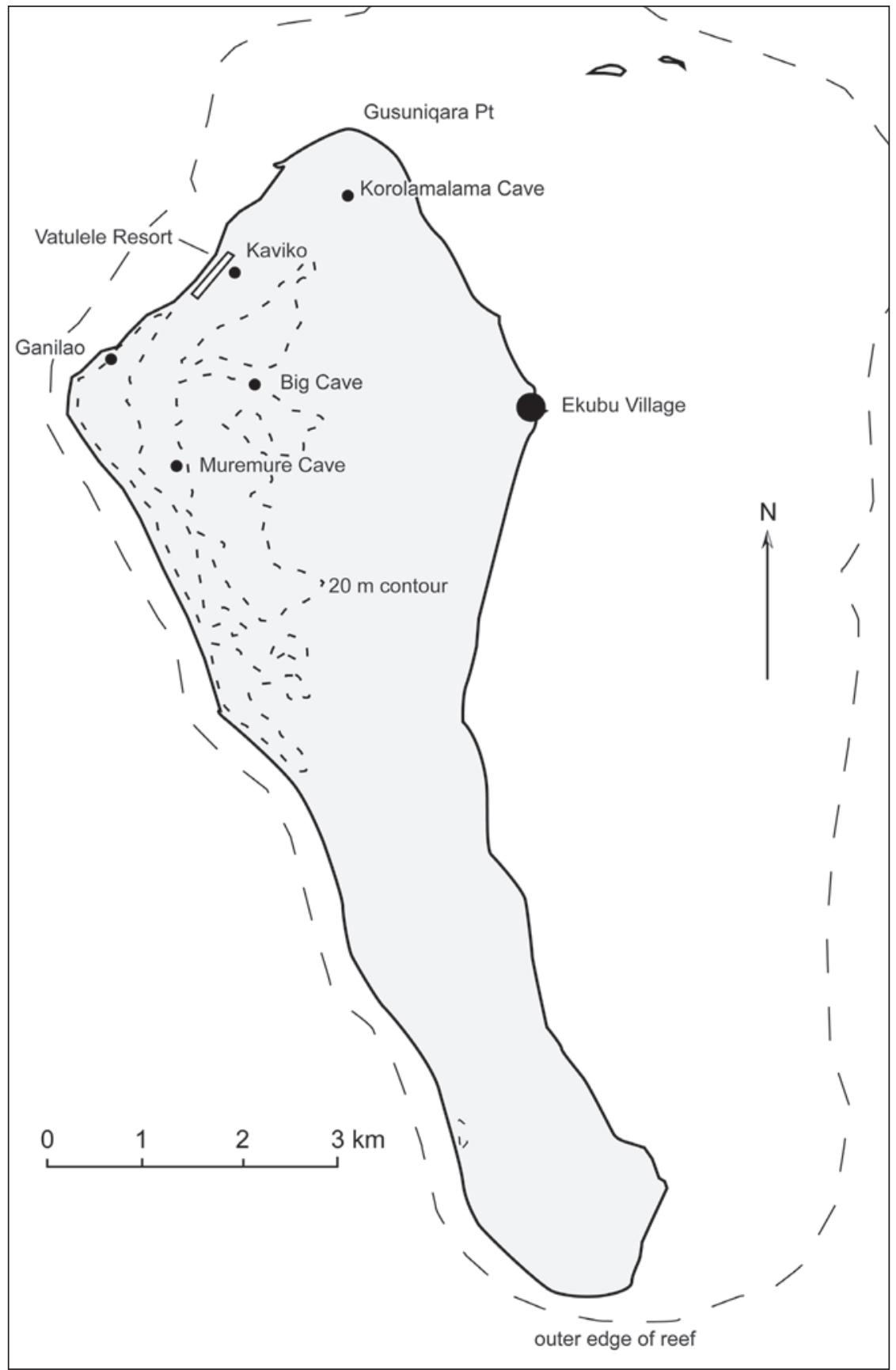

Figure 16. The island of Vatulele showing outer reef limit, $20 \mathrm{~m}$ contour, and the location of the major caves in relation to Ekubu village and Vatulele Resort.

is developed along a major southwest-northeast joint system parallel to the Naura cliff. Muremure does not exhibit marked geological structural control, but rather is typical of phreatic development in unstructured limestone down a shallow drainage gradient, as seen, for example, in Anahulu Cave on Tongatapu (Worthy et al. 1991). Both caves are extensively modified by subsequent drainage, collapse and secondary speleothem development. Most caves on Vatulele have been briefly described by Gansser (1994) and his names for the features are followed here.

The age and geomorphological history of an island are significant factors in predicting features of its fauna, therefore a summary of the geomorphological development of Vatulele is taken from Nunn (1988). Briefly, it began when limestone began accumulating in deep water about 14 million years ago (Ma). Regional uplift resulted in its emergence above sea level towards the end of the Miocene, possibly as early as six Ma. Volcanic activity about 4.72 Ma resulted in lava intruding through the limestone to emerge on the surface, where it is now 
preserved as small exposures at Nabale and Nasarava, near Ekubu village. With the cessation of volcanic activity in the late Pliocene, Vatulele began to gradually subside. However, irregular uplift due to earthquakes, as evidenced by the presence of notches incised in the coastal cliffs, has offset the subsidence. These are best preserved at Gusuniqara Point, where a series of four notches is preserved at $2.2 \mathrm{~m}, 4.0 \mathrm{~m}, 6.2 \mathrm{~m}$ and $7.8 \mathrm{~m}$ above mean sea level. The best preserved notch $(2.2 \mathrm{~m})$, extending along much of the west coast, contains remnants of a lithified infill that has had a Tridacna shell dated from it at 37-38 kyr BP. Nunn (1988) considered that this date and another at $44.7 \mathrm{kyr}$ for the $4.0 \mathrm{~m}$ notch markedly underestimated the true ages, and he interpreted the $2.2 \mathrm{~m}$ notch as representing the high stand of the last interglacial shoreline (ca. $125 \mathrm{kyr} \mathrm{BP}$ ). Then, relative sea level was assumed to be about $6 \mathrm{~m}$ above present level, and so Nunn suggested there had been $3.8 \mathrm{~m}$ subsidence of the island in the past $125 \mathrm{kyr}$.

Palaeosea-level curves indicate that relative sea level has been 70-120 m lower than present from ca. 110 to eight kyr BP (Shackleton 1987), so it is inconceivable that the $2.2 \mathrm{~m}$ notch could have been eroded about $40 \mathrm{kyr}$ BP. Moreover, since the notch was incised, beach deposits were laid up against the cliff between Vetau and Naura beaches, infilling the $2.2 \mathrm{~m}$ notch, and then became lithified with the inclusion of land snails (pers. obs.). The lithification of these sediments would have taken a considerable period of time and thus their presence supports the suggestion that they were deposited at the end of the last interglacial period, about $100 \mathrm{kyr}$ BP. Since sea level attained near its present height in the past 6000 years, these lithified sediments have largely been eroded from the notch, but exposures up to $1 \mathrm{~m}$ thick still remain on the primary wave-cut platform of the beach.

More recently, Nunn (1998) has doubted this sequence of events, and has suggested that all notches were formed within the Holocene. We doubt this for several reasons. Worthy's experience with fossil sites in solution notches in relatively pure Oligocene limestone in New Zealand indicates that cliffs can exhibit little or no headward erosion in 20-30 kyr. The limestone at Vatulele is sufficiently hard and homogenous in its cliff exposures to withstand tens if not hundreds of thousands of years' weathering. Moreover, to infer the sequence of notch excision, formation of beach deposits of coral rubble on the wave platform and infilling the notch, sea level fall, beach sediment consolidation, sea level rise, some erosion of the infill beach deposits, and lastly, the deposition of stalagmitic deposits up to $0.5 \mathrm{~m}$ diameter in the notches, all within the last few thousand years of the Holocene, seems very improbable. Furthermore, the incision of the higher notches under this Holocene scenario requires relative sea level fall (or island rise) which must have been accompanied by downcutting of the present beach platforms, which are incised in limestone, at this same rapid rate of island rise. While problems are well known to exist in dating shell near the limit of radiocarbon dating and gross underestimations of true age are likely, overestimating age is unlikely. However, dating of the speleothem deposits that are seen in several places to also infill these notches would test Nunn's premise. Furthermore, the development of the cave systems has necessarily occurred in concert with the above-ground geomorphology and the notches, and caves the size of Muremure and Big Cave, would require much longer than some 7000 years to form. It is likely they have had their present form for tens if not hundreds of thousands of years: people have certainly occupied the present floors for the past 2000 years.

Thus, we have two contrasting hypotheses of island age. One suggests it may be as old as six $\mathrm{Ma}$, and the other that its subaerial history may be measured at most in hundreds of thousands of years. However, the mere presence of a subaerial landmass does not mean it could sustain much of a terrestrial vertebrate fauna. It would need to have been of a certain minimum size and to have supported a well-developed vegetation community to maintain a diverse avifauna. The 
age of the higher sea level notch, at about $8 \mathrm{~m}$, is probably critical in this respect, as then, the hill at Korolamalama was a protruding rock with marine caves in it and very little of the rest of the island is higher than $20 \mathrm{~m}$, not much of it was outside the impact zone of storm events. In this respect, tsunamis generated from volcanic events in the Tonga or Kermadec Trench regions are likely to have had severe impacts on such a low-lying island.

The fauna of Vatulele has some potential for corroborating either the young or the old hypothesis of island development. If the island has had a long period of subaerial exposure and has been isolated from the mainland, then endemic forms could evolve. No endemic extant taxa are documented, but island endemics are likely to be terrestrial and flightless and the faunal component most prone to human-induced extinction. This is demonstrated to have been the case on Viti Levu (Worthy et al. 1999) and in many other places in the Pacific (e.g. Steadman 1989, 1995). The fossil record of Vatulele can therefore contribute to this debate by determining the former presence or absence of such endemic species.

\section{Big Cave system}

Location: 18 30' 44.7"S, 177³6' 38.2"E. Visits: 8-9 November 1999.

The cave is in walking distance of Vatulele Resort and the main entrance is a recreational destination for visitors to the resort (Figure 16). The main cave, called Big Cave, has a large walk-in type entrance with slopes down to deep pools of water on the left (Figure 17). The chamber is about $30 \mathrm{~m}$ wide and trends northeast but collapsed rocks bar progress beyond about $30 \mathrm{~m}$ in that direction. A few bones were found among the rocks of this chamber, and on the slope in the middle of the chamber just inside the drip-line of the entrance, a deposit of bones from an owl roost was present. On the southwest side of the same entrance feature, another chamber headed southwest contains a large colony of swiftlets. No fossils were found in this section. Off the southeast side of the same entrance feature is another chamber within which no fossil deposits were found.

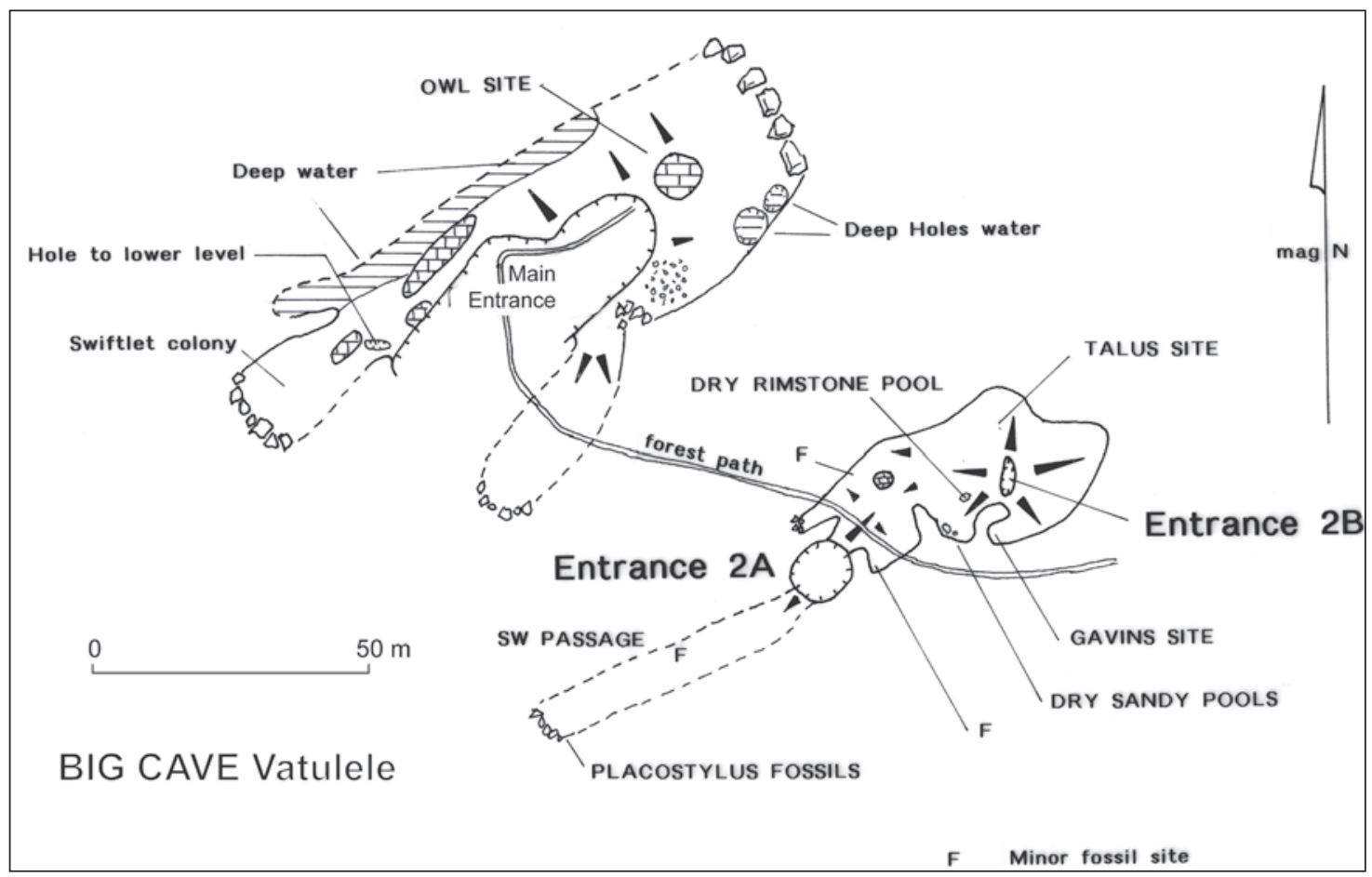

Figure 17. Map of Big Cave, Vatulele Island, showing the location of the major fossil sites. The cave was surveyed with a tape $(0.1 \mathrm{~m})$ and compass $\left(1^{\circ}\right)$. Unsurveyed passages are defined by dashed lines. 
About $70 \mathrm{~m}$ before the main Big Cave entrance, the access path passes two vertical entrances dropping into caves below. The most obvious is an entrance about $10 \mathrm{~m}$ diameter on the southwest side of the path, here called Entrance 2A (Figure 17). About $30 \mathrm{~m}$ distant and on the other side of the path is Entrance $2 \mathrm{~B}$, which is smaller but with more difficult access. The two entrances are connected by a cave passage, and other passages extend either side of them. Many fossils were found in surface deposits in the chamber below Entrance 2B. This is partly because it is an excellent pitfall trap, and partly because its more difficult access meant barn owls could live undisturbed in it. Large deposits of bones accumulated by them are present, but all are post-human-arrival in age, as indicated by the presence of rats.

\section{Ganilao Cave}

The site Ganilao is in a large solution notch in the cliff about $200 \mathrm{~m}$ from the Prawn Grotto, with its base about $7 \mathrm{~m}$ above the ground level (Figure 16). This cave is reputed to have been the home of a legendary giant predatory bird. The site is surrounded by natural forest. The feature is about $5 \mathrm{~m}$ wide and $10 \mathrm{~m}$ long with a high roof, but the bone deposit lies within a hollow about $3 \mathrm{~m}$ wide by $6 \mathrm{~m}$ long.

The deposit is dry and dusty and is mainly an accumulation by barn owls, though nesting white-tailed tropicbirds Phaethon lepturus probably have added some fish bones to it. The surface bone deposit is about $5 \mathrm{~cm}$ deep and overlies consolidated sediments. We sieved the material from an area $3 \mathrm{~m} \times 2.5 \mathrm{~m}$ of the surface deposit through a $6 \mathrm{~mm}$ and a $2 \mathrm{~mm}$ sieve. Material on the $6 \mathrm{~mm}$ sieve was sorted in situ and the concentrate remaining on the $2 \mathrm{~mm}$ sieve was sorted under laboratory conditions. A test pit $20 \mathrm{~cm}$ x $20 \mathrm{~cm}$ was excavated in three $5 \mathrm{~cm}$ spits, after which basement rock was encountered, to assess the faunal composition of the subsurface deposits. Bones were found throughout the subsurface sediments, and charcoal and pottery fragments were present in the first $10 \mathrm{~cm}$, but not in the last $5 \mathrm{~cm}$ above the base. The bones on the surface therefore post-date people inhabiting the island and the cave, but nevertheless provide a rich record of barn-owl prey from a relatively undisturbed forest environment. The site contains a damp ledge at its rear with sediment in it from which a separate sample was collected and analysed. A white-tailed tropicbird with a downy chick occupied an alcove in the site at the time of our visit on 10 November 1999.

\section{Korolamalama Cave}

Korolamalama Cave is in the top of a small hill about $1 \mathrm{~km}$ inland from Gusuniqara Point (Figure 16). The hill is now forested but coconut plantations are close by. Neither bats nor swiftlets were living in the cave at the time of our visit. The hill is basically hollow, as around its summit several entrances lead down into a central, daylight-lit chamber. On the south side of the hill, a distinct, very smoke-blackened passage leads into the hill towards the northeast. There are deep archaeological deposits throughout all cave features and fortification terraces line the hillside. Fossil deposits, if any, are thus deeply buried by archaeological deposits, and their location is impossible to predict. The sample of bones is an accumulation made by barn owls since people last lived in the cave. It comes from the floor of the central chamber in the cave, and was in daylight.

\section{Muremure Cave}

Muremure Cave (Figure 18) is a complex linear system formed by drainage from the centre of the island towards the west coast. We took a GPS reading (18 31' 15.2"S, 177 36' 26.5"E) in 
a small garden clearing on the path traversing the island from the west coast, which is where the path to the cave diverges from it. The cave is about $500 \mathrm{~m}$ from this point at an estimated map reference of $798 \mathrm{E} 313 \mathrm{~N}$. Passages appear to have been formed on one level at or below the water table, as shown by pocket solution features over the walls and roof, but are now entirely drained. In some chambers, speleothem deposition is abundant. In the chambers towards the bat colony from the crawl (Figure 18) and west of the vertical pitfall entrance, all floors are covered in rockfall debris. Between the three entrances, the floors are flat and mainly covered in silt.

The cave is unmapped, but we visited about $1 \mathrm{~km}$ of passage with three entrances on 11 November 1999. Between Entrances 1 and 2, which are horizontal 'walk-in' type features, the floors are much modified by prehistoric human activities, with many stone walls and terraces and infilled hollows. Human burials and pottery fragments are scattered through the cave. The cave depicted by Gansser (1994:Fig. 25) is presumed to be passages seen extending eastward out of the doline, containing what we have called the 'Main Entrance', which we did not visit.

Most fossils were found near the westernmost entrance, which is a vertical 'pitfall' feature, and so trapped ground birds. All were surface deposits. A single barn-owl deposit was seen on the floor in the daylight zone in the middle or second entrance. No potential fossil deposits within sediment sequences were noted. This is the only cave where small bats, presumed to be the sheath-tailed bat Emballonura semicaudata, were seen alive. Swiftlets were not present.

\section{Caves around the resort}

On 10 November 1999 we visited caves close to the resort. Kaviko Cave is a small, drowned feature with no accessible deposits. Another small cave, partially developed for the resort, was also too close to the water table and no deposits of interest were noted. Lastly, Bua Cave, on the path leading towards Ekubu village, is about $5 \mathrm{~m}$ wide and $10 \mathrm{~m}$ long. Again, it is close to the water table, and has no entrapment mechanism to accumulate fossils.

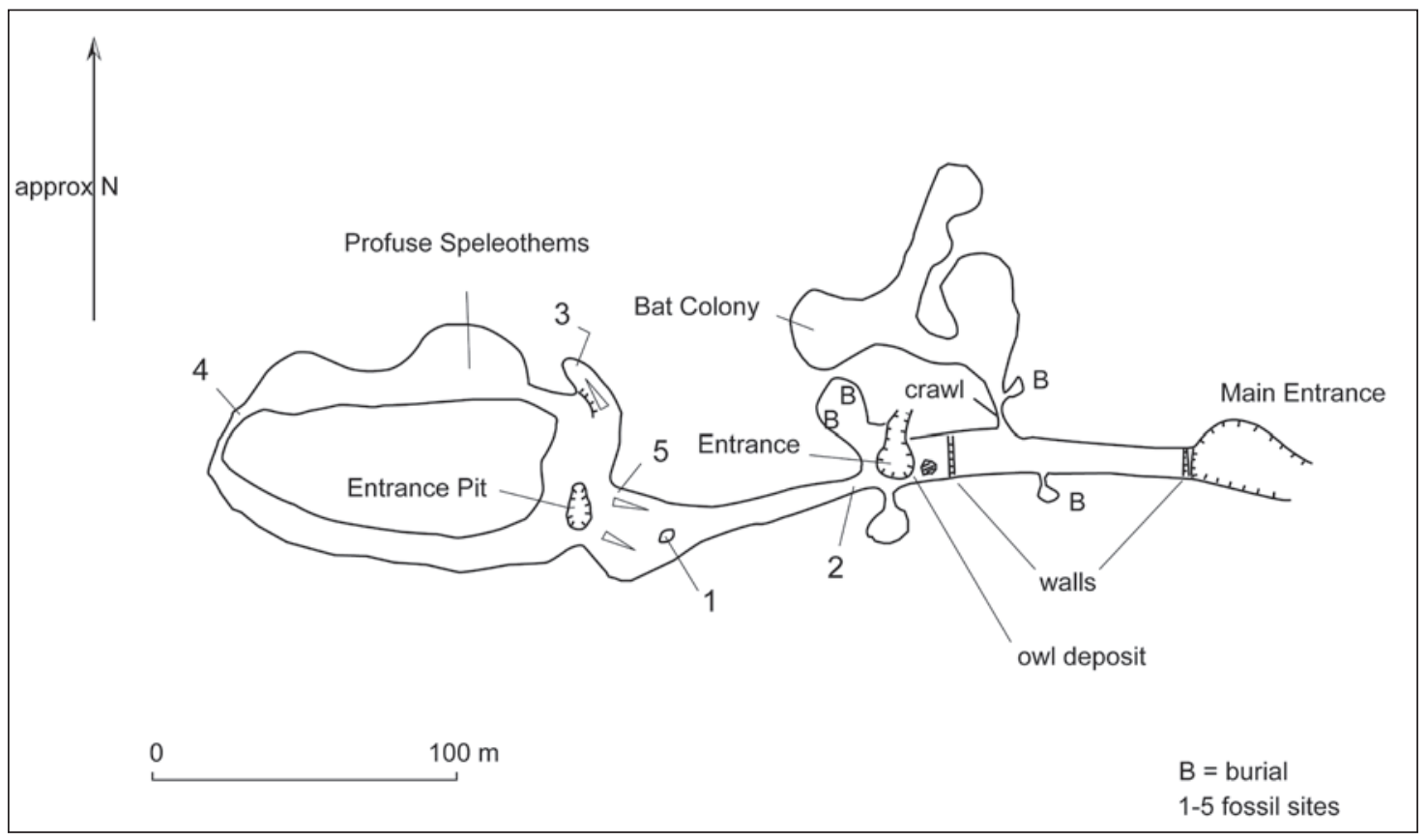

Figure 18. Sketch map of Muremure Cave, Vatulele Island. 


\section{References}

Anderson, A.J., Ayliffe, L., Questiaux, D., Sorovi-Vunidilo, T., Spooner, N. and Worthy, T. 2001. The terminal age of the Fijian megafauna. In: Anderson, A.J., Lilley, I. and O'Connor, S. (eds), Histories of Old ages: Essays in honour of Rhys Jones, pp. 251-264. Pandanus Books, ANU, Canberra.

Baumel, J.J. and Witmer, L.M. 1993. Osteologia. In: Baumel, J.J., King, A.S., Breazile, J.E., Evans, H.E and Vanden Berge, J.C. (eds), Handbook of avian anatomy: Nomina Anatomica Avium, Second Edition. Publications of the Nuttall Ornithological Club 23: 45-132. Cambridge, Massachusetts, USA.

Gansser, A. 1994. Enigmas of Vatulele Island. La Buona Stampa, Switzerland.

Gilbert, T. 1984. Limestone and volcanic caves of the Fiji Islands. Transactions of the British Cave Research Association 11(2): 105-118.

Nunn, P.D. 1988. Vatulele, a study in the geomorphological development of a Fiji island. Mineral Resources Department Memoir 2, Fiji.

Nunn, P.D. 1998. Uplift of islands along the Vatulele-Beqa ridge. In: Pacific Island Landscapes, pp. 43-60. Institute of Pacific Studies, The University of the South Pacific, Suva.

Shackleton, N.J. 1987. Oxygen isotopes, ice volume and sea-level. Quaternary Science Review 6: 183-190.

Steadman, D.W. 1989. Extinction of birds in Eastern Polynesia: A review of the record, and comparisons with other Pacific Island groups. Journal of Archaeological Science 16: 177-205.

Steadman, D.W. 1995. Prehistoric extinctions of Pacific island birds: Biodiversity meets zooarchaeology. Science 267: 1123-1131.

Worthy, T.H. and Anderson, A. 1999. Research on the caves of Viti Levu, Fiji, June 1997 - October 1998, and their significance for palaeontology and archaeology. Report to the Fiji Museum, ANH, RSPAS, ANU, Canberra.

Worthy, T.H., Wilde, K. and Williams, D. 1991. Anahulu Cave, Tongatapu. New Zealand Speleological Bulletin 8: 525-528.

Worthy, T.H., Anderson, A.J. and Molnar, R.E. 1999. Megafaunal expression in a land without mammals - the first fossil faunas from terrestrial deposits in Fiji (Vertebrata: Amphibia, Reptilia, Aves). Senckenbergiana biologica 79(2): 237-242. 